\title{
PARTIAL REPLACEMENT OF CEMENT WITH RICE HUSK ASH IN CONCRETE PRODUCTION: AN EXPLORATORY COST-BENEFIT ANALYSIS FOR LOW-INCOME COMMUNITIES
} pages: $127-141$

\author{
Franco Muleya ${ }^{\circledR}$ Natasha MuWila \\ Chipozya Kosta TeMbo Alice lungu
}

\begin{abstract}
A B S T R A C T
Cement is an important construction material in concrete production; however, it is expensive and unaffordable for many low-income and rural communities in developing countries. Rice husk is a by-product from the rice mill process, with an approximate ratio of $200 \mathrm{~kg}$ rice husk per one tonne of rice produced. This experimental study aimed to investigate the integrity of concrete produced in Zambia using rice husk ash (RHA) to partially replace cement. The primary goal was to carry out a cost-benefit analysis on the use of RHA in concrete. RHA was used to partially replace cement with ratios of $10 \%, 20 \%$ and $30 \%$. The $20 \%$ cement replacement mix produced the optimum $18 \mathrm{MPa}$ concrete strength results at a 0.5 water/binder ratio. This translated in cost reduction of concrete by $12.5 \%$, which is particularly significant for higher concrete volumes. The produced concrete is suitable for lightly loaded structures, such as foundation footings, surface beds and walkways to benefit low-income communities. The study further concluded that the RHA based concrete was more cost-efficient in structures that were close to areas of rice production due to reduced RHA transportation costs.
\end{abstract}

KEY WORDS

rice husk ash, partial replacement, concrete, cost reduction

10.2478/emj-2021-0026
Franco Muleya

The Copperbelt University, Zambia ORCID 0000-0002-3552-6198

Corresponding author: email: muleyaf@yahoo.co.uk

Natasha Muwila

Adam Hood Consulting, Zambia ORCID 0000-0003-2352-6120

Chipozya Kosta Tembo

The Copperbelt University, Zambia ORCID 0000-0001-5195-0821

Alice Lungu

The Copperbelt University, Zambia ORCID 0000-0002-7963-9856

\section{INTRODUCTION}

The construction industry has experienced major innovations in concrete production methods alternative to conventional concrete. Naik (2008) states that when applied correctly, concrete production innova- tions encourage sustainability, reduce project delivery time, improve on-site waste management, and reduce the total construction cost. According to Singh (2008), sustainability has become a worldwide goal. Green or sustainable buildings use key resources like

Muleya, F., Muwila, N., Tembo, Ch. K., \& Lungu, A. (2021). Partial replacement of cement with rice husk ash in concrete production: an exploratory cost-benefit analysis for low-income communities. Engineering Management in Production and Services, 13(3), 127-141. doi: 10.2478/emj-2021-0026 
energy, water, minerals and land much more efficiently than those merely built according to codes. Fapohunda et al. (2017) state that global warming triggered by the emission of greenhouse gases, such as carbon dioxide (CO2), into the atmosphere can be reduced by replacing gas-emitting materials. One of these substitute materials is rice husk ash (RHA), which has been established as a suitable material for the partial replacement of portland cement in concrete production. Alam (2015) states that rice husk is not recommended for human consumption because of its less nutritional content and its irregular abrasive surfaces, which are not naturally degraded, thereby presenting the potential to cause serious healthrelated problems. Many studies have been conducted on the use of rice husk for many decades and have proved that one tonne of rice produces $200 \mathrm{~kg}$ of rice husk, which translates into $40 \mathrm{~kg}$ of ash. This represents $20 \%$ of husk and $4 \%$ of ash (Zareei, 2017; Bui, 2001; Fapohunda et al., 2017).

\section{BACKGROUND}

According to the Second National Rice Development Strategy (2016 - 2020), the SNRDS (2016), Zambia had been on average producing about 44512 metric tonnes of paddy rice (approx. 29000 metric tonnes in milled rice) annually between 2010 and 2016. However, a deficit in production resulted from consumption plateauing at 60000 metric tonnes (approx. 39000 metric tonnes in milled rice). Paddy rice is rice covered by husks. During the same sixyear timeframe (2010 - 2016), the SNRDS (2016) reported that Zambia had a rice deficit resulting in the importation of between 5000 and 20000 metric tonnes of milled rice annually to meet domestic demand. Zambia's failure to produce rice to meet local demand was mainly attributed to limited access to improved varieties and quality seed, poor farming practices, poor water management system, low level of mechanisation, inadequate human and institutional capacity and limited access to seasonal and long-term finance.

The SNRDS (2016) further shows that rice production occurred in different regions, including Lusaka, Central and Copperbelt provinces considered rural or remote from the main economic activity centres. The report underpinned by the Ministry of Agriculture states that rice is produced in ten of the eleven Zambian provinces (Table 1). Table 2 shows a breakdown of average rice production by province, showing an average of 44512 metric tonnes for the whole country in the period $2010-2016$. Table 2 further indicates that most rice production occurs in rural provinces, such as Eastern, Luapula, Muchinga, Northern and Western. The provinces and their rice fields are home to many households with compromised infrastructure, which could be improved with the provision of cheaper concrete based on rice husk - the material currently treated as waste. Fig. 1 shows the most recent recorded yet lower rice production levels in Zambia at 29584 metric tonnes in 2019. Based on the rice husk production levels amounting to $20 \%$ of rice production, the estimated produced husk was 5917 tonnes, translating into 1 183 tonnes of rice husk ash. Further, Fig. 1 shows that rice production began to significantly increase in 2008 , resulting in a corresponding increase in rice husk and ash at the time. Currently, no documented information is available on established cost-benefit analysis on the use of rice husk ash to partially substitute portland cement in Zambia. As a result, this research set out to determine the properties exhibited by concrete produced using Zambian RHA and to carry out a cost-benefit analysis of this concrete. Lit-

Tab. 1. Key features of rice production in Zambia between 2010 and 2016

\begin{tabular}{|l|c|}
\hline \multicolumn{1}{|c|}{ Province } & $\begin{array}{c}\text { Percentage Of Rice Production HeCtarage } \\
\text { Covering 38 537 HeCtares [\%] }\end{array}$ \\
\hline Western Province & 46 \\
\hline Northern Province & 32 \\
\hline Muchinga Province & 13 \\
\hline Luapula Province & 4 \\
\hline Eastern Province & 4 \\
\hline Other provinces, namely: Central, Southern, Copperbelt, Northwestern and Lusaka & 1 \\
\hline
\end{tabular}

Source: (SNRDS, 2016) 
Tab. 2. Basic rice data by region in Zambia (average $2010 / 11$ to $2014 / 15$ )

\begin{tabular}{|c|c|c|c|c|c|c|}
\hline Provinces & $\begin{array}{l}\text { NUMBER OF } \\
\text { HOUSEHOLDS } \\
\text { GROWING }\end{array}$ & $\begin{array}{l}\text { AREA PLANTED } \\
\text { (HA) }\end{array}$ & $\begin{array}{c}\text { AREA HARVEST- } \\
\text { ED (HA) }\end{array}$ & $\begin{array}{l}\text { PRODUCTION } \\
\text { (MT) }\end{array}$ & YIELD (MT/HA) & $\begin{array}{l}\text { AVERAGE RICE } \\
\text { PLOT SIZE PER } \\
\text { HOUSEHOLD }\end{array}$ \\
\hline Central & 177 & 72 & 66 & 129 & 1.38 & 0.41 \\
\hline Copperbelt & 93 & 25 & 23 & 33 & 1.46 & 0.27 \\
\hline Eastern & 5385 & 1581 & 1472 & 2437 & 1.55 & 0.29 \\
\hline Luapula & 5570 & 1569 & 1390 & 2731 & 1.78 & 0.28 \\
\hline Lusaka & 164 & 50 & 42 & 64 & 1.06 & 0.31 \\
\hline Muchinga & 13020 & 4823 & 4513 & 7931 & 1.66 & 0.37 \\
\hline Northern & 15893 & 12413 & 11315 & 16182 & 1.31 & 0.78 \\
\hline Northwestern & 1096 & 345 & 315 & 509 & 1.51 & 0.31 \\
\hline Southern & 109 & 37 & 28 & 17 & 0.26 & 0.33 \\
\hline Western & 26542 & 17622 & 9038 & 14479 & 0.90 & 0.66 \\
\hline National & 68051 & 38537 & 28202 & 44512 & 1.16 & 0.57 \\
\hline
\end{tabular}

Source: SNRDS, 2016.

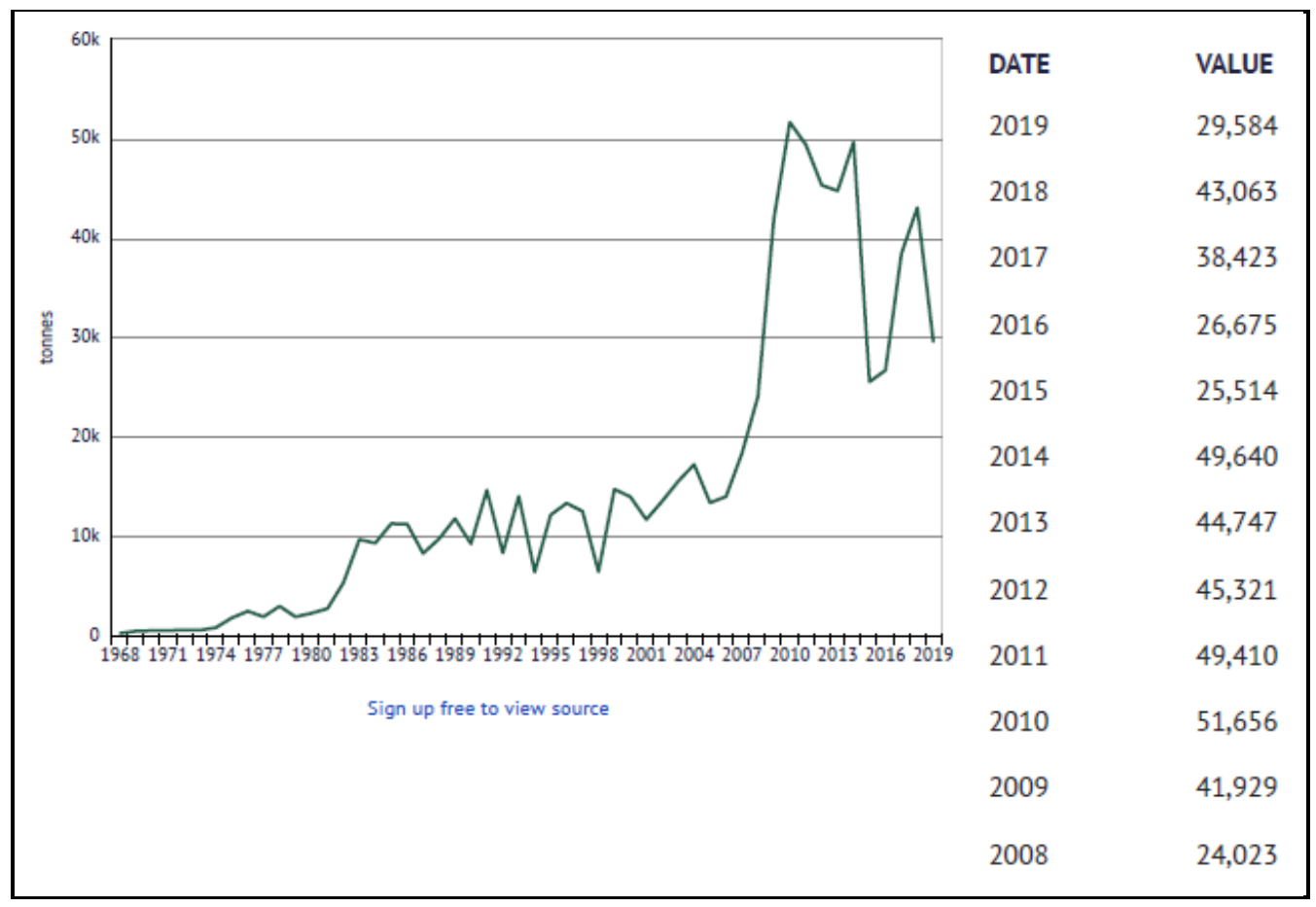

Fig. 1. Zambia's rice production from 1978 to 2019

Source: https://knoema.com/atlas/Zambia/topics/Agriculture/Crops-Production-Quantity-tonnes/Rice-paddy-production.

erature indicates that much of the studies on this subject have concentrated on the feasibility of attaining functional RHA-based concrete and its properties.

Particularly in Zambia, the cost-effectiveness of using this type of concrete has not been addressed. The study was therefore positioned to investigate the functionality and cost-effectiveness of using RHAbased concrete as a measure of reducing the unit cost of concrete using RHA while retaining the structural integrity of the concrete. The functionality of the RHA-based concrete was also considered comparing the performance of local RHA with global patterns through literature review.

The ultimate objective of this paper was to establish the benefits of using RHA in rice-growing rural communities of Zambia (Tables 1 and 2) as a way of bringing down the cost of concrete and improving the infrastructure, mainly developed using unimproved clay. This solution would eventually improve 


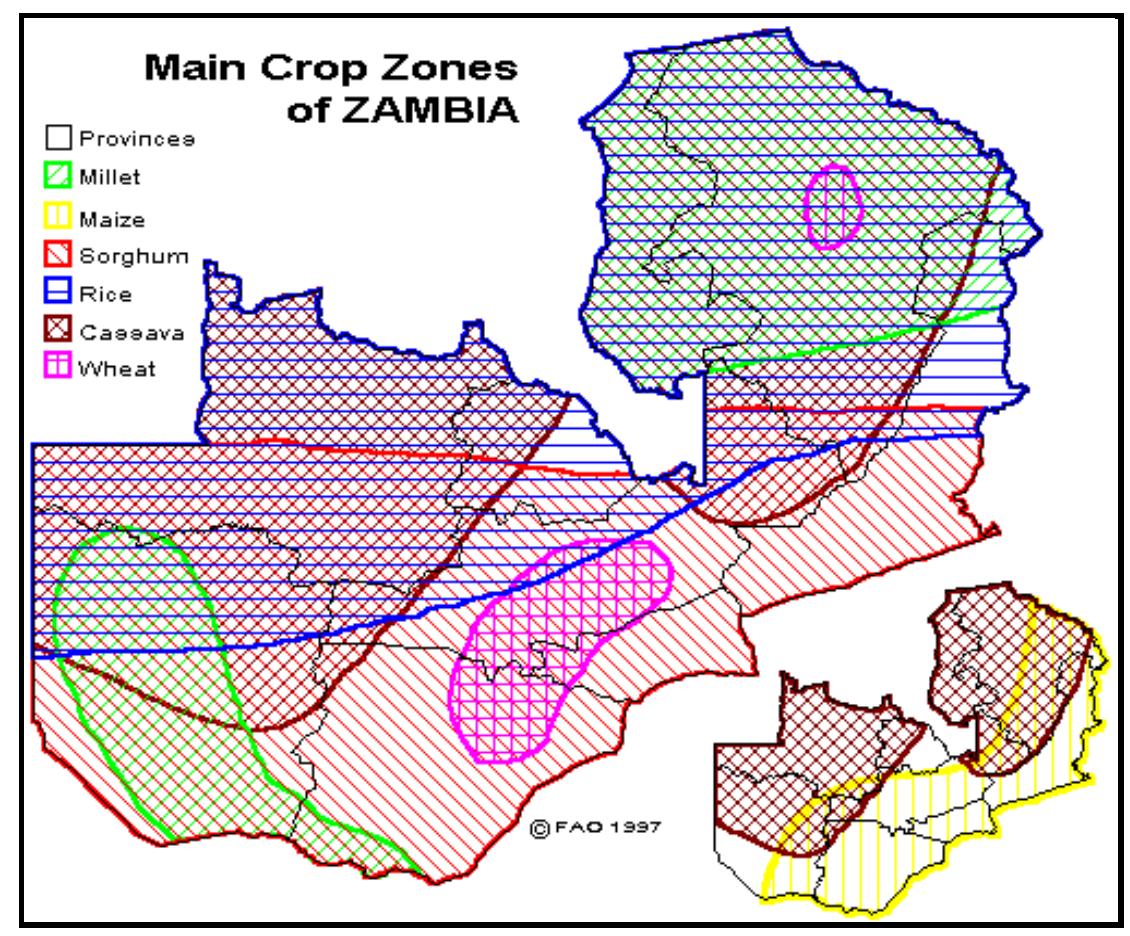

Fig. 2. Map of Zambia showing rice-growing area and provinces as discussed in Background

Source: https://www.pinterest.com/pin/770467448725782191/.

the livelihood and quality of life of rural communities in rice-growing areas. Currently, the produced rice husk goes to waste but could be turned into a useful green construction material resource as already described. Fig. 2 shows the rice-growing area and provinces as discussed in Background.

\section{LITERATURE REVIEW}

As part of the global sustainability agenda to reduce carbon footprint and stay as environmentally friendly as possible, cement and sand replacement materials in concrete exist in various forms, such as blast furnace slag, which is a by-product of iron manufacturing used as a substitute for cement (Pal et al., 2003; Divsholi et al., 2014; Salvador et al., 2019; Ozbay et al., 2016; Mo et al., 2015). Fly ash, a fine powder, which is a by-product of burning pulverised coal in electric generation power plants, has been used to partially replace cement and sand in concrete (Christy \& Tensing, 2010; Dhaka \& Roy, 2015; Muhit et al., 2013; Jatio et al., 2019; Rajamane et al., 2007; Rafieizonooz et al., 2016; Reshma et al., 2021; Rajagopalan, 2019; Podolyakina, 2016; Białas, 2016). Copper tailings have also been used to partially replace sand and cement in concrete to reduce the depletion of natural resources (Muleya et al., 2020; Dandautiya
\& Singh, 2019; Kundu et al., 2016; Swetha et al., 2015). Environmental benefit analysis has been performed for many of these studies, which indicate significant absorption of waste from dumpsites while reducing the cost of concrete (Muleya et al., 2020).

The use of agricultural residue, particularly rice residue, is not a new concept in the construction industry. It can be dated back to as early as the 1950s, when Egypt adopted several low-cost housing strategies (Allam \& Garas, 2010). Loamy Nile mud mixed with straw resulted in strong bricks. A sun-baked mud brick with the addition of rice straw made it three times stronger (Allam \& Garas, 2010). Many other studies indicated in the next passage have investigated the performance of rice husk ash as a partial replacement of cement in the production of concrete. A study by Pode (2016) states that rice husk is an agricultural waste abundantly available in riceproducing countries, such as India, Bangladesh, Brazil, China, Cambodia, the USA, Myanmar, Vietnam, and Southeast Asia. Despite attaining large annual production levels of rice worldwide, $\mathrm{RH}$ has only been recycled for low-value applications. Siddika et al. (2020) and Thiedeitz et al. (2020) affirms that rice husk ash (RHA) is a good supplementary cementitious material for concrete production because of its low energy demand and negligible greenhouse gas emission in addition to high pozzolanic reactivity. 
Further, the study concluded that RHA had demonstrated its ability to improve concrete strength and durability properties, in addition to the reduced construction and carbon emissions.

\subsection{Chemical Constituents AND PROPERTIES OF Rice HuSK ASH}

The study of the RHA chemical composition is one of the most important parts because it provides clues on the behaviour of RHA. Table 3 shows a summary and average values of the chemical composition of RHA as presented by Fapohunda et al. (2017), derived from 30 different studies by 30 different authors from 1992 to 2016. Table 3 shows that silica

Tab. 3. Oxide composition of RHA

\begin{tabular}{|l|r|}
\hline \multicolumn{1}{|c|}{ ConstituentS } & $\begin{array}{r}\text { AVERAGE PERCENTAGES BASED } \\
\text { ON 30 STUDIES/AUTHORS } \\
\text { BETWEEN 1992 TO 2016 }\end{array}$ \\
\hline Silica $\left(\mathrm{SiO}_{2}\right)$ & 87.90 \\
\hline Alumina $\left(\mathrm{Al}_{2} \mathrm{O}_{3}\right)$ & 0.69 \\
\hline Iron Oxide $\left(\mathrm{Fe}_{2} \mathrm{O}_{3}\right)$ & 0.55 \\
\hline Calcium Oxide $(\mathrm{CaO})$ & 1.00 \\
\hline magnesium Oxide $(\mathrm{MgO})$ & 0.54 \\
\hline Sulphur Oxide $\left(\mathrm{SO}_{3}\right)$ & 0.34 \\
\hline Sodium Oxide $\left(\mathrm{Na}_{2} \mathrm{O}\right)$ & 0.56 \\
\hline Potassium Oxide $\left(\mathrm{K}_{2} \mathrm{O}\right)$ & 2.26 \\
\hline Loss of Ignition $(\mathrm{LOI})$ & 5.52 \\
\hline Total (SAF) SiO $+\mathrm{Al}_{2} \mathrm{O}_{3}+\mathrm{Fe}_{2} \mathrm{O}_{3}$ & 89.05 \\
\hline
\end{tabular}

Source: (Fapohunda et al., 2017).
(SiO2) was the most dominant of all oxides in RHA, with the lowest value of $73.60 \%$ and the highest $97.53 \%$. The average for the 30 studies was $87.9 \%$. Further, the total sum of silica, alumina and iron oxide (SAF) (Table 3) also exceeds $70 \%$, averaging 89.05 in the 30 studies as shown in Table 3 . All the RHA specimens demonstrated that the RHA belongs to the same category as the Class F fly ash. Research results by Siddika et al. (2020) were consistent with findings by Fapohunda et al. (2017) on the oxide content of RHA, which has high pozzolanic characteristics. Table 1 clearly indicates that all research results presented a very high silica content of above $70 \%$. This is a measure of the RHA reactivity. Silica is the compound responsible for the strength in concrete (Fapohunda et al., 2017).

Studies in ten countries by various researchers (Muthadhi \& Kothandaraman 2007; Joel, 2010; Muthandhi \& Kothandaraman, 2010; Oyekan \& Kamiyo, 2011) revealed that high content of silica ranges from $67 \%$ to $93.1 \%$ and SAF content from 70 $\%$ to $93.52 \%$. The countries included Brazil, Canada, Guyana, India, Iraq, Japan, Malaysia, Nigeria, Thailand, the USA and Vietnam, indicating a very wide and global span of the studies. It is worth noting that the 30 pieces of research and the research in ten countries harvested the optimal concrete compressive strength from between $10 \%$ and $30 \%$ cement replacement with RHA. These results were consistent with those by Fapohunda et al. (2017). Additionally, there seems to be variedness in the results, making it harder to generalise the study findings without cor-

Tab. 4. Summary of RHA and associated output from various authors

\begin{tabular}{|c|c|c|c|c|c|c|c|c|}
\hline \multirow{2}{*}{$\begin{array}{c}\text { RICE HUSK ASH \% } \\
\text { REPLACEMENT FOR } \\
\text { CEMENT } \\
\\
\text { AUTHORS }\end{array}$} & \multicolumn{2}{|c|}{0 \% RHA (CONTROL MIX) } & \multicolumn{2}{|c|}{$10 \%$ RHA } & \multicolumn{2}{|c|}{$20 \%$ RHA } & \multicolumn{2}{|c|}{$30 \%$ RHA } \\
\hline & $\begin{array}{c}\text { COM- } \\
\text { PRESSIVE } \\
\text { STRENGTH } \\
\text { (MPA) }\end{array}$ & $\begin{array}{l}\text { DENSITY } \\
\left(K G / M^{3}\right)\end{array}$ & $\begin{array}{c}\text { COM- } \\
\text { PRESSIVE } \\
\text { STRENGTH } \\
\text { (MPA) }\end{array}$ & $\begin{array}{l}\text { DENSITY } \\
\left(K G / M^{3}\right)\end{array}$ & $\begin{array}{c}\text { COM- } \\
\text { PRESSIVE } \\
\text { STRENGTH } \\
\text { (MPA) }\end{array}$ & $\begin{array}{l}\text { DENSITY } \\
\left(K G / M^{3}\right)\end{array}$ & $\begin{array}{c}\text { COM- } \\
\text { PRESSIVE } \\
\text { STRENGTH } \\
\text { (MPA) }\end{array}$ & $\begin{array}{l}\text { DENSITY } \\
\left(\mathrm{KG} / \mathrm{M}^{3}\right)\end{array}$ \\
\hline Obilade (2014) & 29.15 & 2430 & 20.88 & 2300 & 18.59 & 2290 & 13.29 & 2280 \\
\hline Al-Khalaf \& Yousif (1984) & 23.30 & - & 25.40 & - & 24.10 & - & 22.80 & - \\
\hline Ephraim et al. (2012) & N/A & - & 22.00 & - & 20.00 & - & 19.00 & - \\
\hline Akeke et al. (2013) & N/A & - & 22.00 & 2017 & 20.00 & 1950 & 19.00 & 19 \\
\hline Krishna et al. (2017) & 27.00 & - & 29.80 & - & 16.03 & - & - & - \\
\hline Krishna et al. (2015) & 39.00 & - & 40.50 & - & - & - & 32.50 & - \\
\hline Ahsan \& Hossain (2018) & 36.10 & - & 22.80 & 2323 & 16.80 & 23 & & - \\
\hline
\end{tabular}


responding findings and experiments. The compressive strength of concrete is an important property because it underpins the design of structural concrete and defines compliance as a means of field quality control.

Research by Calica (2008) indicates that a mixture containing RHA requires more water compared to those without it, and the water demand increased with more replacement of the cement by the ash. This is attributed to the porous structure of rice husk, which induces a large surface area. However, the workability or fluidity of the mix can be improved by using a good superplasticiser. Table 4 provides a summary of RHA and associated output from various authors as a way of establishing optimum outputs of partial cement revealment of concrete with RHA. The table shows selected RHA-based concrete showing portland cement replacement by RHA from $10 \%$ to $30 \%$ along with compressive strength and density outputs. The table is consistent with the earlier results of other scholars.

\section{RESEARCH METHODS}

Research methodology focuses on general laws and principles of arranging the research activity and selecting an efficient, adequate and rational research technique (Novikov \& Novikov, 2019). The research took the quantitative approach, which Creswell (2009) defined as the employment of inquiry strategies, such as experiments and surveys. Further, numerical data was collected using predetermined instruments to yield quantifiable data that can be subjected to statistical treatment or analysis. The study was positivist philosophically and, therefore, deductive. The research was mainly driven by experiments underpinned by a literature review on the partial replacement of concrete elements with RHA

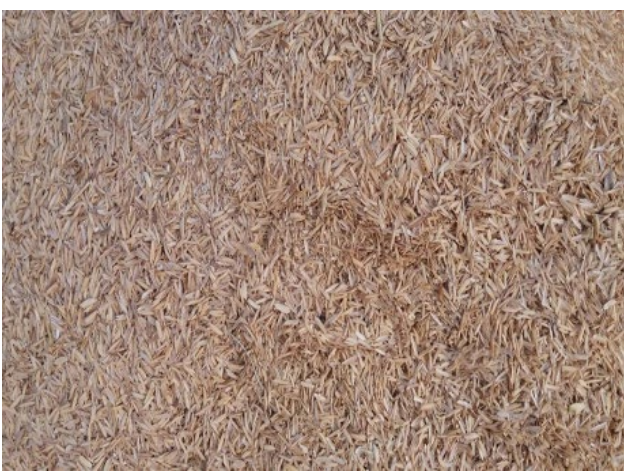

Fig. 3. Rice husks in concrete production. The experimental stage explored the suitability of RHA as a partial replacement of cement in concrete. Further, the optimum percentage of cement was established that could be replaced by RHA in concrete production. The optimum cement replacement refers to the maximum amount of cement that can be partially replaced by RHA without compromising the concrete's safety, integrity and intended function. Laboratory experiments were used to achieve the aim of the study. Fresh concrete was prepared for carrying out slump and workability tests. Slump and compaction factor tests were used to establish concrete workability and later cast six concrete cubes for each mix to obtain the average values for each mix for quality control purposes. A total of 30 concrete cubes, including trial mixes, were cast and completely immersed in water in a curing tank for 28 days to obtain the estimated maximum strength of the concrete cubes.

The study focused on the final concrete product for end-users as an exploratory study, and, thus, all the concrete cubes were tested at 28 days except for trial cubes which were tested at seven days to check for the rate of concrete strength accumulation. Hallingberg et al. (2018) and Muleya et al. (2020) define exploratory research as a study generating the information required to decide how to proceed with a full-scale effectiveness trial, mainly referred to as the pilot or feasibility stage, to prove the concept at hand. The density tests and compressive strength tests constituted the hardened concrete tests. The compressive strength was determined by using a digital compressive strength testing machine shown in Fig. 9. Results of the fresh and hardened concrete are shown in Tables 5 and 6 . The reference or control mix did not have the RHA content while other mixes did, ranging from $10 \%$ as a minimum to $30 \%$ as a maximum cement replacement with RHA, which is consistent with the majority of literature results from the

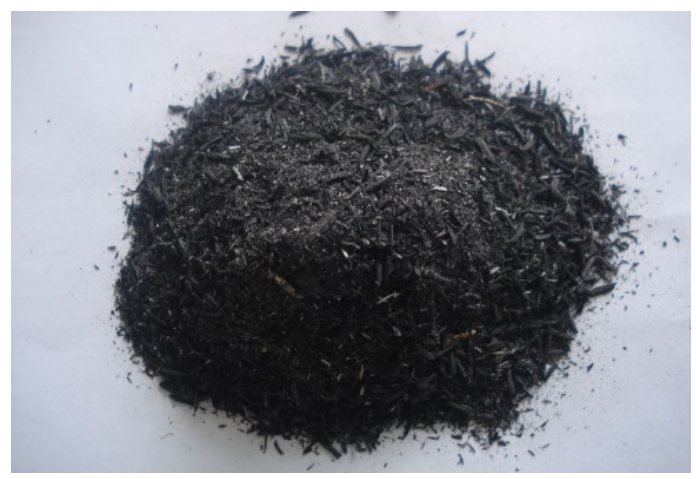

Fig. 4. Rice husk ash 
review because replacements beyond $30 \%$ of RHA were not sustainable due to weakening concrete compressive strength unless superplasticiser is introduced in correct amounts to counteract fluid and compressive strength deterioration. Isolated analysis was used to establish the optimum percentage of cement replacement with RHA. Muleya et al. (2020) define isolated analysis as the process of holding all variables constant while manipulating one of them to determine its influence and effect on the properties of the whole element.

The main criteria for determining the quality of the materials were concrete strength driven by concrete-mix design (Emmitt and Gorse, 2014). In this research, the manipulated variable was RHA, which was added in percentages ranging from $0-30 \%$ to obtain values for concrete workability, density and compressive strength. Due to the high-water absorption effect of RHA, as seen in the literature review, two water-cement ratios were selected, namely 0.3 and 0.5 , to observe the behaviour of the two mixes under the influence of RHA. The two mixes were used to establish the suitability of RHA as a partial replacement of cement in concrete. According to Le and Ludwig (2016), Van et al. (2018), Sharma (2014) and Kanthe (2021), the introduction of superplasticisers to RHA-based concrete improves concrete fluidity and results in improved concrete compressive strength by different values depending on the type of superplasticiser and the quality or grade of used cement.

However, this study did not consider the use of superplasticisers because it was exploratory in nature and designed to address the needs of low-income communities with an extremely budget. Besides, the availability and use of plasticisers in Zambia is still unexplored. A future study with the introduction of superplasticisers and longer curing periods is recommended to resolve this study limitation. Fine aggregate, coarse aggregate and portland cement were secured from credible local sources. $\mathrm{RH}$ was obtained from the National Milling Company (NMC), which sources rice from fields across the country. The $\mathrm{RH}$ was obtained raw and later brunt in an incinerator at 600 degrees to remove carbon and to grind into ash. The RH was left to burn for two days with no further fuelling. It was then allowed to cool for another 24 hours. A pulverisation machine was used to produce fine RHA particles as a final cement replacement. Figs. 3 and 4 show rice husks and rice husk ash, respectively, as captured from the experimental process for this research.

\section{RESEARCH RESULTS AND DISCUSSION}

The compressive strength test results showed that the mix proportions of aggregates used for both concrete cubes of 0.3 and $0.5 \mathrm{w} / \mathrm{c}$ ratio yielded $33 \mathrm{MPa}$ and $25 \mathrm{MPa}$, respectively, for normal concrete after 28 days. While the compressive strength outcomes appear to be low for the given water-cement ratio, the results are consistent with other research (Muleya et al., 2020; Kunda, 2014; Sharma, 2014; Olafusi \& Olutoge, 2012). With compressive strength expected to be around $42 \mathrm{MPa}$ and higher, as seen in some findings (Singh, 2018; Ramezanianpour et al., 2009; Zareei, 2017; Muleya \& Nwaubani, 2018), the results of this study demonstrate the need to carry out further trial mixes and investigation of cement quality particularly in developing economies. A study by Muleya (2000) revealed that cement for high-strength performance concrete in pile foundations had to be imported because the local cement could not meet the minimum compressive strength of the concretemix design. Table 4 illustrates the changes in compressive strength at different RHA percentages. The incorporation of RHA into the concrete using as little as $10 \%$ for replacement results in a decrease in compressive strength both after seven and 28 days of curing. The RHA mixes did not develop a compressive strength comparable to that of the control mix. A less workable mix yields a less dense cube as compared to the concrete mix, as seen in Table 5. This outcome ensues because of friction between the particles causing them to compact less as compared to a more fluid mix. A 0.5 mix resulted in better water absorption by the rice husk ash resulting in more free water to allow complete mixing of the material fractions. While the results of this study meet the objectives to provide cheaper concrete for low-income communities in rice-growing areas, the introduction of superplasticisers in the RHA-based concrete circumvents the challengers of low concrete fluidity and reduced compressive strength. The superplasticiserbased concrete needs longer curing periods, such as 90 days, to understand its full behaviour and properties. This forms a part of the study limitation for widely used RHA-based concrete beyond low-income community requirements. Table 5 compares the recorded results at different $0 \%, 10 \%, 20 \%$ and $30 \%$ cement replacement with RHA for the two concrete mixes ( 0.3 and 0.5$)$ from the main experiments of the study. 


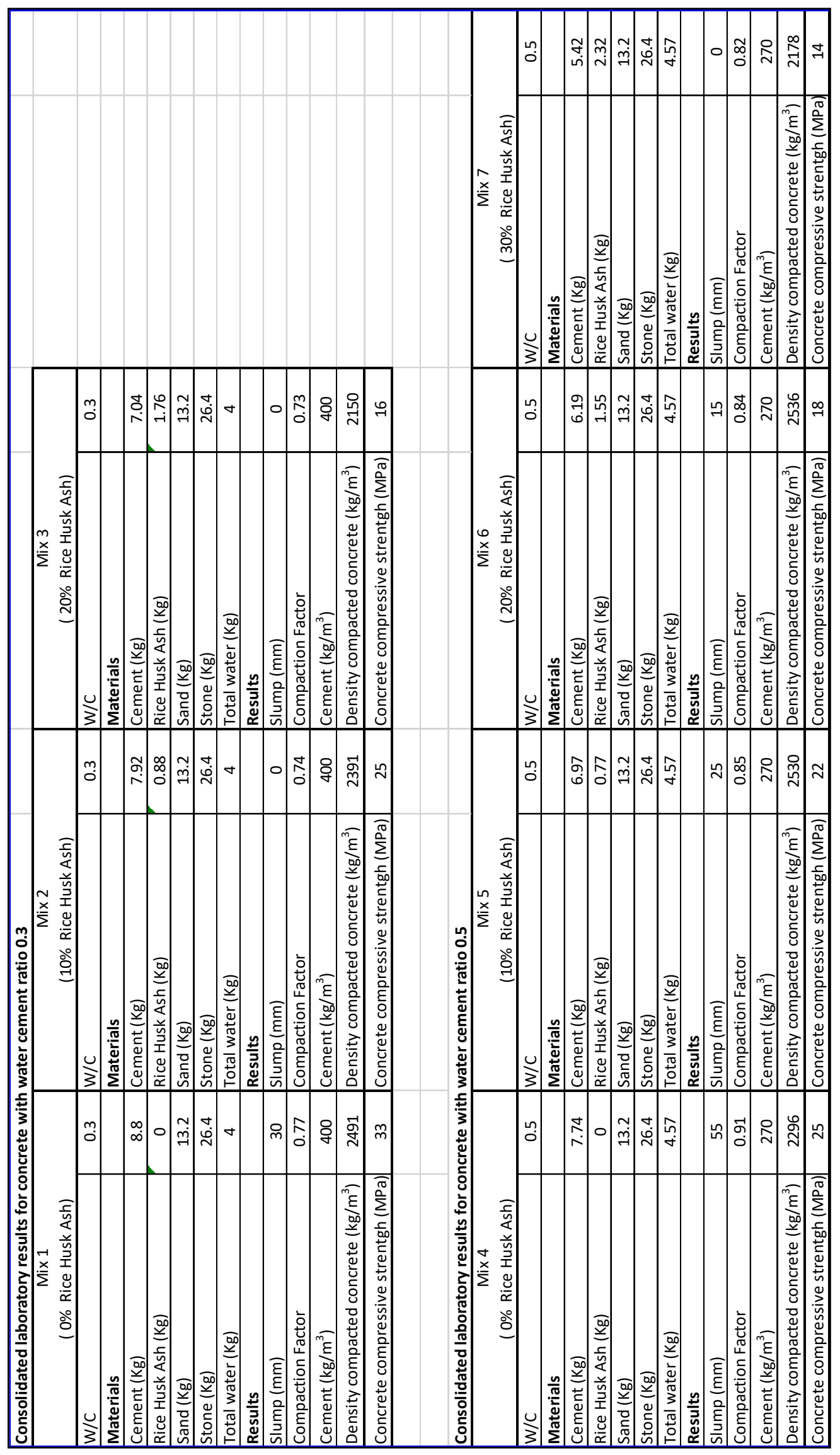




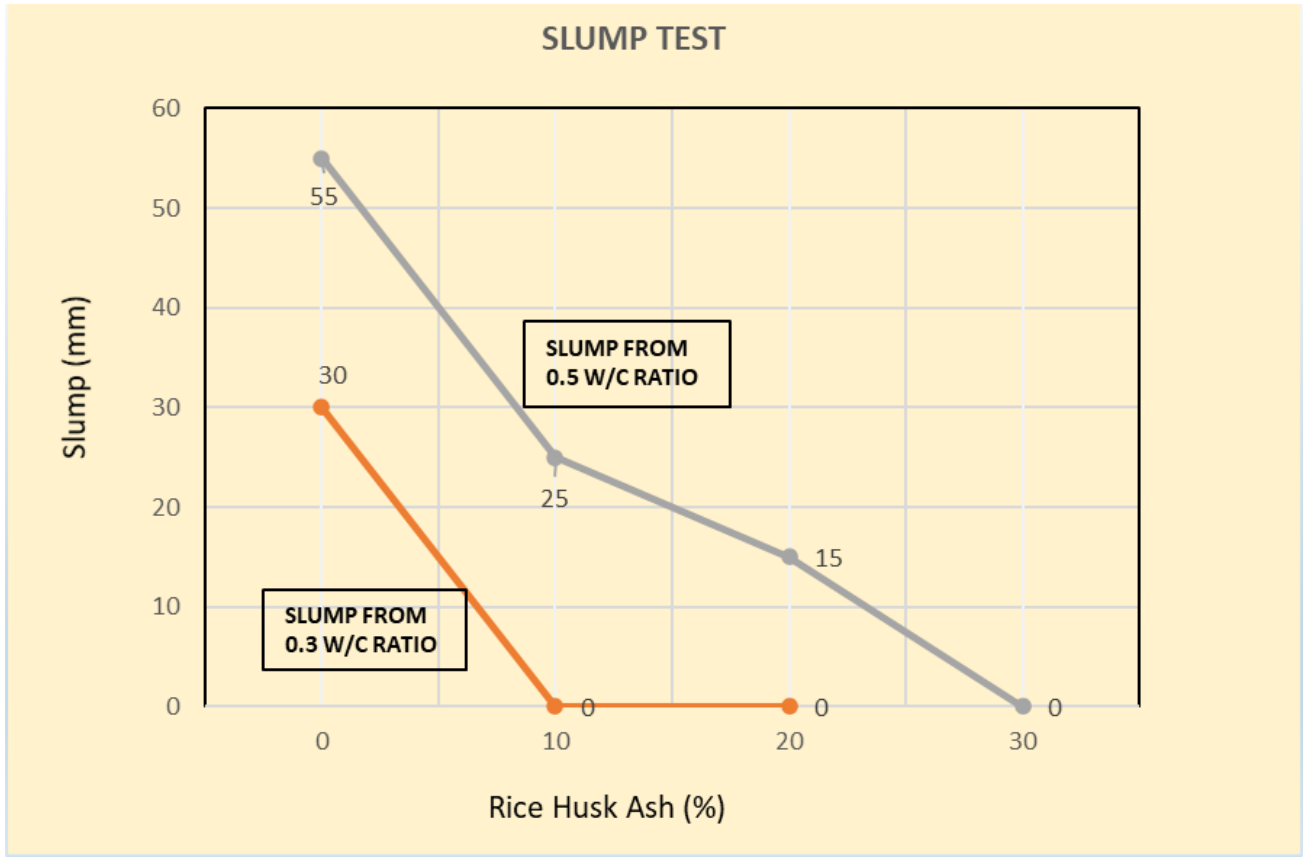

Fig. 5. Slump test showing concrete workability for 0.3 and 0.5 water-cement ratios

Fig. 5 shows the gradual decrease in the slump or workability of the concrete in relation to the increase in the partial replacement of cement with RHA. The results clearly indicate that introduction of RHA results in the decrease of concrete workability. Fig. 6 shows the slump test in progress.

The less fluid concrete mix of 0.3 water-cement ratio got to $0 \mathrm{~mm}$ slump faster with a $10 \%$ addition of RHA compared to a more fluid mix of 0.5 watercement ratio, which got to $0 \mathrm{~mm}$ slump with a $20 \%$ and $30 \%$ addition of RHA. The effect of RHA on the slump of fresh concrete is the exact opposite of the effect of copper tailings on partial replacement of sand in concrete, as reported by Muleya et al. (2020). The introduction of copper tailings in concrete results in an increased slump or concrete workability. The replacement of cement with RHA in the 0.3 watercement ratio only went up to $20 \%$ because the concrete was not fluid beyond that point. In the 0.5 water-cement ratio, concrete fluidity only became impossible beyond $30 \%$ of adding RHA because of the higher water content compared to the 0.3 water ratio mix.

Fig. 7 shows the effect of RHA on the compressive strength of concrete with respect to a gradual increase of RHA in partially replacing cement by up to $30 \%$. As expected, the 0.3 and 0.5 water-cement ratio mixes without RHA were found to be $33 \mathrm{MPa}$ and $25 \mathrm{MPa}$, respectively, at 28 days. Results indicated that both water-cement ratio mixes decreased in compressive strength. Figs. 8 and 9 show the hard test process of the concrete strength with the introduction of RHA. Interestingly, at a $20 \%$ replacement of cement by RHA, the 0.5 water cement-ratio mix became stronger than the 0.3 water-cement ratio. At this point, the 0.3 water-cement ratio mix could not be mixed beyond $20 \%$ of RHA addition because the mix was too dry, triggered by the dehydrating effect of RHA on concrete. Beyond $15 \%$ of RHA addition,

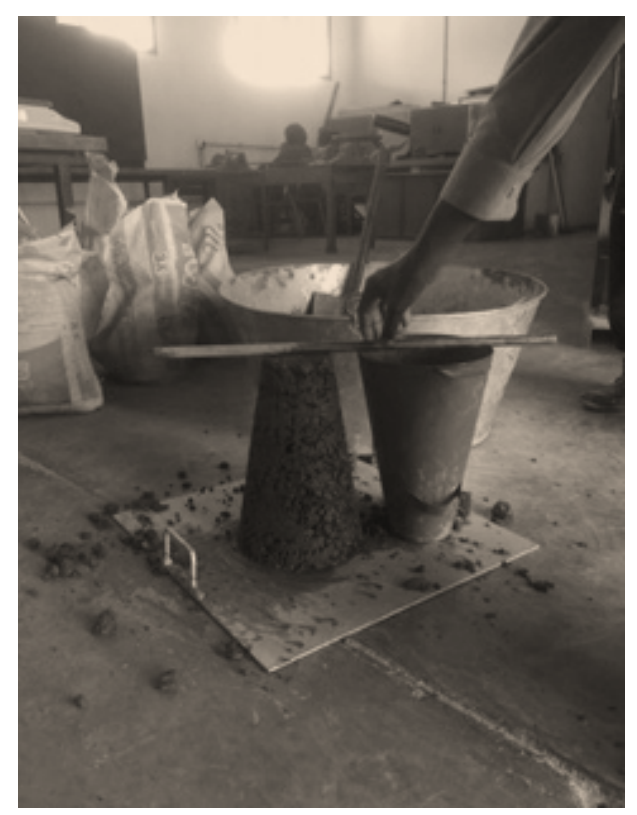

Fig. 6. Slump test in progress 


\section{COMPRESSIVE STRENTGH FOR WATER CEMENT RATIOS 0.3 AND 0.5 \\ AFTER 28 DAYS}

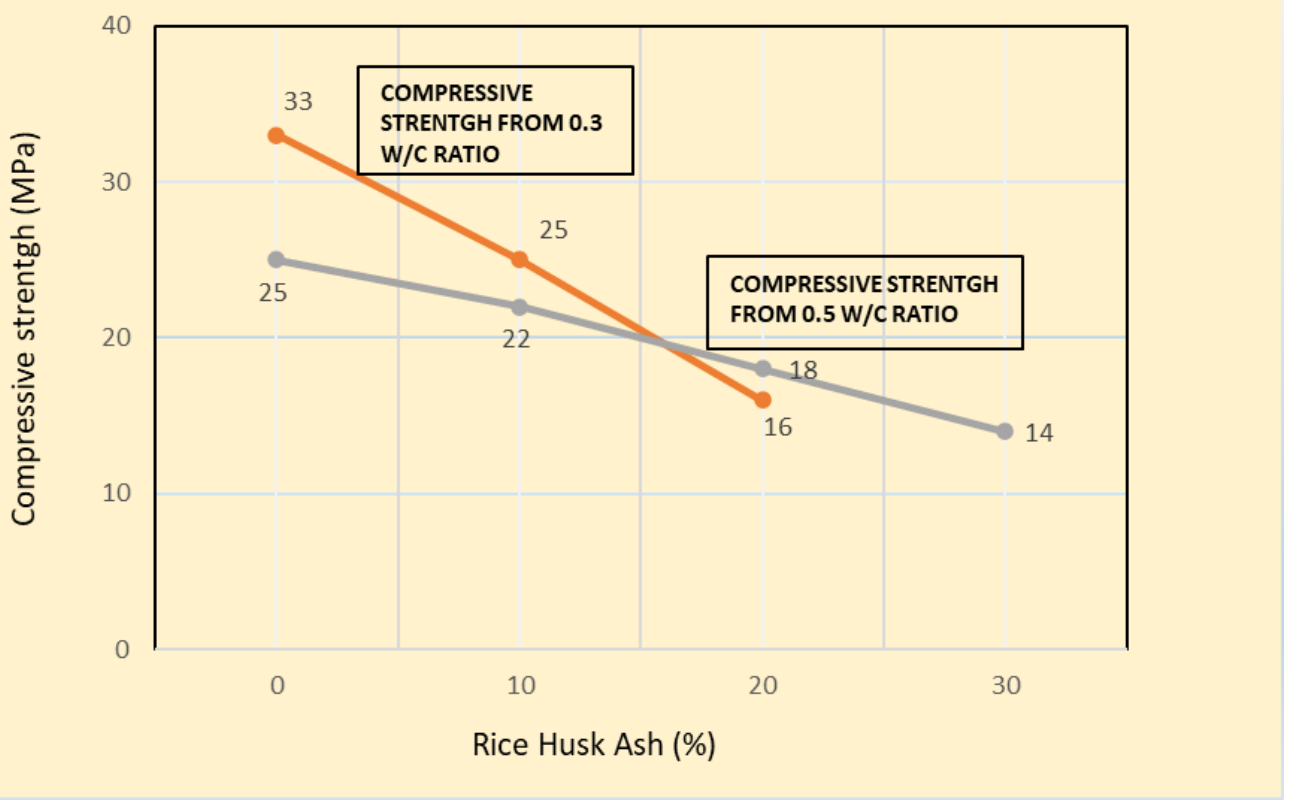

Fig. 7. Compressive strength for 0.3 and 0.5 water-cement ratios

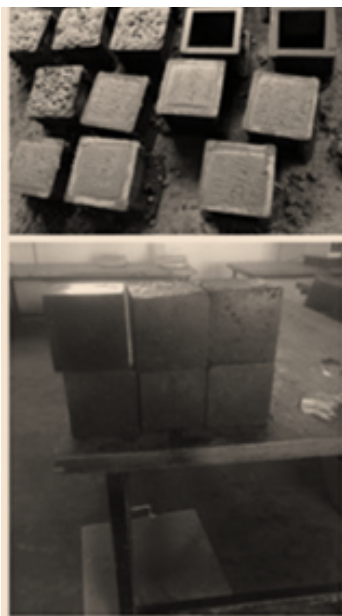

Fig. 8. Concrete cube curing

the 0.5 water-cement ratio mix became stronger than the 0.3 water-cement ratio, and yet it is the cheaper mix because of the lower cement content. $18 \mathrm{MPa}$ and $14 \mathrm{MPa}$ as lower-strength concrete from 0.5 watercement ratio mix can be used in various areas of rural communities, such as foundation footings, slabs and crop handling platforms.

\subsection{EFFECT OF RICE HUSK ASH ON CONCRETE DENSITY}

Fig. 10 shows the concrete density changes for the 0.3 and 0.5 water-cement ratios with respect to increasing partial replacement quantities of cement

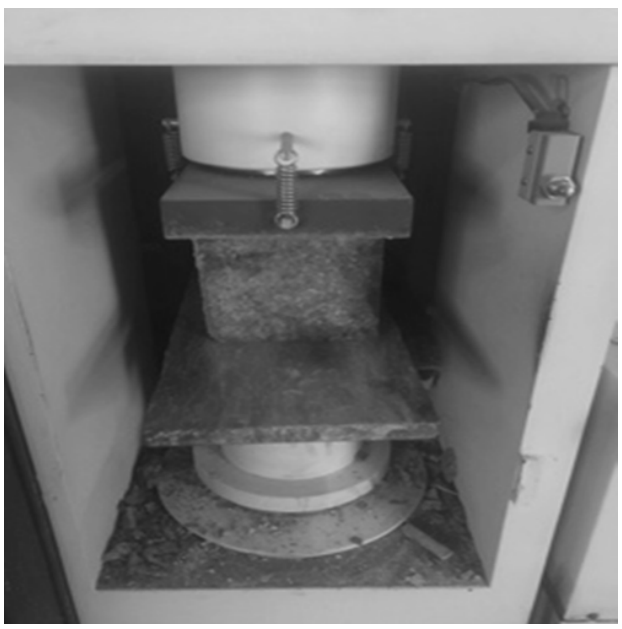

Fig. 9. Compressive strength testing in progress

with RHA. The 0.3 water-cement ratio mix had the highest densities at $0 \%$ and $10 \%$ cement replacement, amounting to $2491 \mathrm{~kg} / \mathrm{m}^{3}$ and $2391 \mathrm{~kg} / \mathrm{m}^{3}$, respectively, while the 0.5 water-cement ratio has its highest densities at $10 \%$ and $20 \%$ cement replacement translating to $2530 \mathrm{~kg} / \mathrm{m}^{3}$ and $2536 \mathrm{~kg} / \mathrm{m}^{3}$, respectively. The 0.5 water-cement ratio $\mathrm{mix}$ had higher densities due to the full compaction because of the adequate water content compared to the less fluid mix influenced by the dehydrating effect of RHA. This result is consistent with that of the compressive strength being higher in the wet mix than the dry mix at a high percentage level of cement replacement with 


\section{CONCRETE DENSITY FOR WATER CEMENT RATIOS 0.3 AND 0.5 AT 28 DAYS}

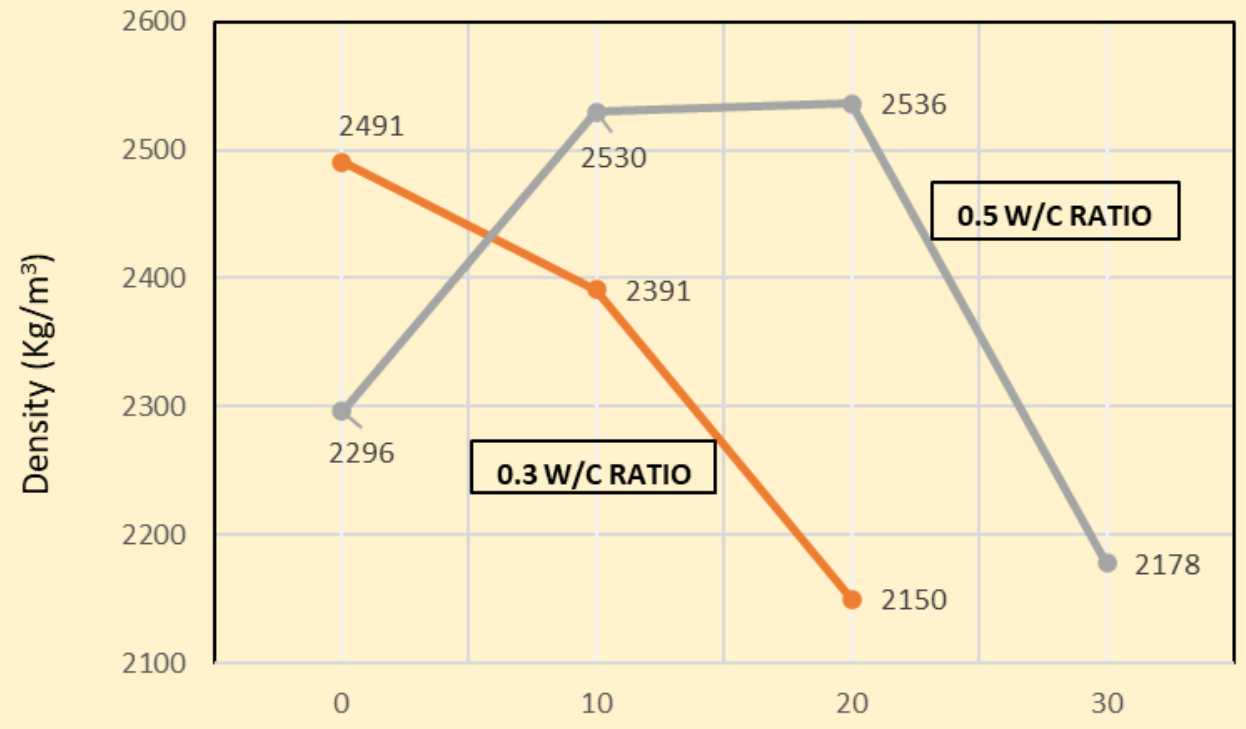

Rice Husk Ash (\%)

Fig. 10. Concrete density for 0.3 and 0.5 water cement ratios

RHA. These results strongly indicate that higher replacement quantities of cement with RHA is best suited for the more fluid mix of 0.5 water-cement ratio. This result is true for the compressive strength and the density of the concrete.

\subsection{COST-BENEFIT ANALYSIS OF RICE HUSK ASH-BASED CONCRETE}

Fig. 11 indicates the cost savings of concrete based on the partial replacement of cement with

\section{COST SAVING WITH RESPECT TO INCREASE IN RHA BASED ON 0.5 W/C RATIO}

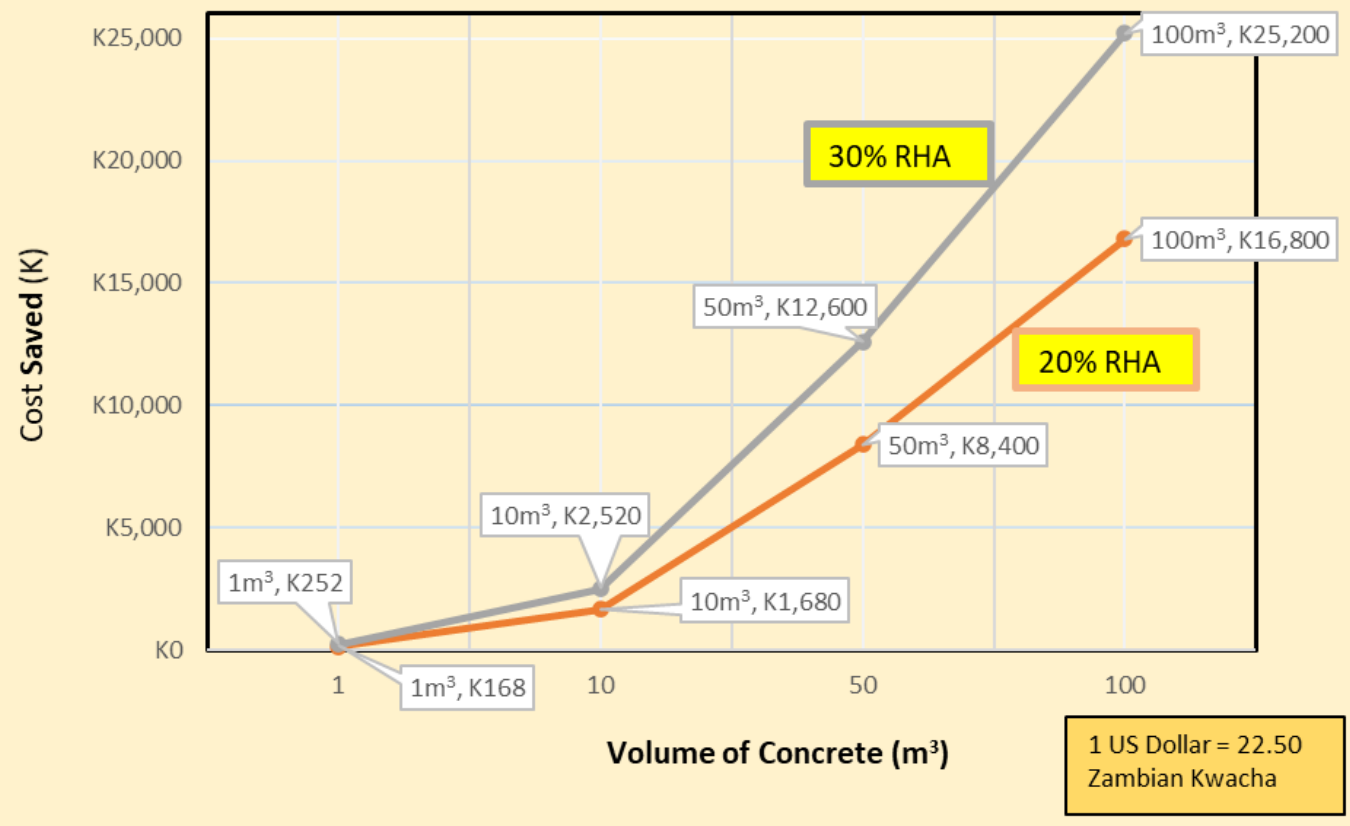

Fig. 11. Cost saving analysis for RHA-based concrete at a 0.5 water-cement ratio 
RHA. Results indicate that the optimum cement replacement with RHA was at $20 \%$, and this is only applicable to the 0.5 water-cement ratio mix because it was more fluid and workable, as already explained under the slump and compressive strength subheadings. Fig. 10 shows that a saving of ZMW 1680 (USD 74.6) can be made on $20 \%$ RHA content for every 10 $\mathrm{m}^{3}$ of $18 \mathrm{Mpa}$ concrete made, while a saving of ZMW 2520 (USD 112) saving can be made on 30 \% RHA content for every $10 \mathrm{~m}^{3}$ of $14 \mathrm{MPa}$ concrete, which is suitable for light duty concrete uses. These amounts of savings are significant for Zambian rural residents, making this information highly valuable and beneficial to rural rice-growing communities. These savings would significantly contribute to improved livelihood as the money could be used on other development projects or poverty alleviation. All these savings are based on the 0.5 water-cement ratio, which is the cheaper concrete because it uses less cement content even before replacing some of the cement with RHA.

\section{VALUE AND BENEFITS OF THE RESEARCH TO THE INDUSTRY}

The research acknowledges the use of RHA as cement replacement, as seen in the literature review section. First, the study revealed that the local RHA in Zambia performs just like other RHAs in other countries and, therefore, can be used to partially replace cement in concrete, as seen from the results section of the paper. This is because the results are consistent with the literature review findings. Secondly and most importantly, the results from this research provide valuable information to rice growers in Zambian rural areas on how they can turn the rice husk waste to ash that can be used to improve the quality of their infrastructure. Many households in rural Zambia use clay floors and surface beds for house floors. The rice husk ash would help to reduce the cost of concrete, thereby making affordable concrete for the structures. A major contribution to livelihood improvement can be made by converting waste into a useful resource for making cheaper and affordable concrete. The rural Zambian rice-growing communities may not afford sophisticated furnaces to produce rice husk ash, but local kilns used for making clay burnt bricks may be used for that purpose. These results may be extended to other regions of the continent in promoting the use of RHA as a partial replacement of cement in the rural rice-grow- ing regions. Although many scholars have widely studied this topic for decades, this is the first known paper offering a detailed cost-benefit analysis of the RHA use in concrete in the Zambian construction for the benefit of the rural rice-growing communities as a way of improving the quality of their physical infrastructure, including housing and other agricultural infrastructure support systems.

\section{LIMITATIONS OF THE RESEARCH}

As an exploratory study, the research focussed on fully-cured concrete results at 28 days for analysis. Other experiments, such as cumulative compressive strength at seven, 14 and 21 days and beyond 28 days for normal concrete and RHA-based concrete, were not carried out because the primary properties of RHA-based concrete performance needed to be established in this exploratory research. Concrete results at 28 days were enough to make a conclusive analysis of this exploratory study. Besides, the study did not use a superplasticiser to overcome concrete fluidity and compressive strength challenges caused by the introduction of RHA. The next study, which will be full-scale, will introduce a superplasticiser along with cement tests and trail mixes to ensure that all parameters are established at the beginning of the study. It must be noted that there is no established data to confirm the performance of cement and plasticisers in Zambia, hence, the need to carry out detailed cement tests and multiple concrete mix trials.

\section{CONCLUSIONS}

The research revealed that many studies had been undertaken on partial replacement of cement with up to $30 \%$ of RHA to produce good and functional concrete. Besides, the research established that it was feasible to utilise RHA as a way of turning it from waste to a resource. The study indicates that the optimal cement replacement by RHA was $20 \%$ and $30 \%$, which resulted in concrete compressive strength of 18 $\mathrm{Mpa}$ and $14 \mathrm{MPa}$ at $0.5 \mathrm{~W} / \mathrm{C}$ ratio, respectively. This concrete grade can be used in foundation footings, medium-duty concrete surface beds, agricultural working bays etc. Unlike many other papers on the same subject, this paper presents cost-benefit analysis particularly aimed at improving livelihood for rural communities in rice-growing areas. The results 
indicated that cost benefits were applicable to significant volumes of cheaper concrete production with savings of ZMW 1680 (USD 74.6) for every $10 \mathrm{~m}^{3}$ of $18 \mathrm{MPa}$ concrete produced using a $20 \%$ cement replacement with RHA. This translated into the cost reduction of concrete by $12.5 \%$, which is significant, particularly for higher volumes of concrete. Further, a saving of ZMW 2520 (USD 112) for every $10 \mathrm{~m}^{3}$ of $14 \mathrm{MPa}$ concrete produced using a $30 \%$ cement replacement with RHA. This research has provided useful data that can be used to make informed decisions by rice-growing communities in the use of RHA as concrete resource material. An education programme would need to be designed to train ricegrowing communities to use RHA and partial cement material.

Although the study objective was reached by confirming that RHA-based concrete is functional in low-income communities, one limitation of the study remains, i.e., the strength tests at 60 days and 90 days were not performed; therefore, future studies could consider making strength tests beyond 28 days in addition to introducing other elements, such as fly ash, copper tailings and other waste materials that may be recycled in an effort to reduce the depletion of natural resources while bringing down the cost of concrete.

Further, the use of superplasticisers must be explored at many levels of concrete production, especially for cement and fine aggregate replacementbased concrete to improve fluidity and performance. This study has also demonstrated that cement testing and multiple trial mixes are important before proceeding with full-scale studies and industry application.

\section{ACKNOWLEDGEMENTS}

The publication of the article for 11th International Conference on Engineering, Project, and Production Management - EPPM2021 was financed in the framework of the contract no. DNK/ SN/465770/2020 by the Ministry of Science and Higher Education within the "Excellent Science" programme.

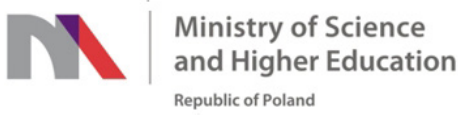

\section{LITERATURE}

Ahsan, M. B., \& Hossain, Z. (2018). Supplemental use of rice husk ash (RHA) as a cementitious material in concrete industry. Construction and Building Materials, 178, 1-9. doi: 10.1016/j.conbuildmat.2018.05.101

Akeke, G. A., Ephraim, M. E., Akobo, I. Z. S., \& Ukpata, J. O. (2013). Structural properties of rice husk ash concrete. International Journal of Engineering, 3(3), 8269.

Alam, S. (2015). Properties of brick aggregate concrete using rice husk ash (RHA) cement as binding material. Master thesis. Dhaka, Bangladesh: Bangladesh University of Engineering \& Technology.

Al-Khalaf, M. N., \& Yousif, H. A. (1984). Use of rice husk ash in concrete. International Journal of Cement Composites and Lightweight Concrete, 6(4), 241-248.

Allam, M., \& Garas, G. (2010). Recycled chopped rice straw-cement bricks: an analytical and economical study. WIT Transactions on Ecology and the Environment, 140, 79-86.

Białas, A. (2016). Cost-benefits aspects in risk management. Polish Journal of Management Studies, 14(1), 28-39.

Bui, D. D. (2001). Rice Husk Ash as a Mineral Admixture for High Performance Concrete. $\mathrm{PhD}$ thesis. Delft, The Netherlands: University of Technology.

Calica Jr, M. G. (2008). Influence of rice husk ash as supplementary material in cement paste and concrete. NLR Journal, 2, 80-92.

Chanda Kunda (2000). Blending natural fine aggregate with recycled fine aggregate to produce concrete. Thesis. Zambia: Copperbelt University.

Christy, C. F., \& Tensing, D. (2010). Effect of Class-F fly ash as partial replacement with cement and fine aggregate in mortar. Indian Journal of Engineering and Materials Sciences, 17, 140-144.

Creswell, J. W. (2009). Research Design Qualitative, Quantitative and Mixed Methods Approaches. 3rd ed. Los Angeles: SAGE Publications Inc.

Dandautiya, R., \& Singh, A. P. (2019). Utilization potential of fly ash and copper tailings in concrete as partial replacement of cement along with life cycle assessment. Waste Management, 99, 90-101.

Dhaka, J. K., \& Roy, S. (2015). Utilization of fly ash and cow dung ash as partial replacement of cement in concrete. International Journal of Civil \& Structural Engineering, 6(1), 34-39.

Divsholi, B. S., Lim, T. Y. D., \& Teng, S. (2014). Durability properties and microstructure of ground granulated blast furnace slag cement concrete. International Journal of Concrete Structures and Materials, 8(2), 157-164.

Emmitt, S., \& Gorse, C. A. (2014). Advanced Construction of Buildings. 3rd ed. John Wiley and Sons.

Ephraim, M. E., Akeke, G. A., \& Ukpata, J. O. (2012). Compressive strength of concrete with rice husk ash as partial replacement of ordinary Portland cement. Scholarly Journal of Engineering Research, 1(2), 32-36.

Fapohunda, C., Akinbile, B., \& Shittu, A. (2017). Structure and properties of mortar and concrete with rice husk 
ash as partial replacement of ordinary Portland cement - A review. International Journal of Sustainable Built Environment, 6(2), 675-692.

Hallingberg, B., Turley, R., Segrott, J., Wight, D., Craig, P., Moore, L., \& Moore, G. (2018). Exploratory studies to decide whether and how to proceed with full-scale evaluations of public health interventions: a systematic review of guidance. Pilot and Feasibility Studies, 4(1), 1-12.

Jatoi, M. A., Solangi, G. S., Shaikh, F. A., \& Rajput, S. (2019). Effect of Lakhra fly ash as partial replacement of cement in traditional concrete. Mehran University Research Journal of Engineering \& Technology, 38(4), 1045-1056.

Joel, M. (2010). A review of partial replacement of cement with some agro wastes. Nigerian Journal of Technology, 29(2), 12-20.

Kanthe, V. N. (2021). Effect of Superplasticizer on Strength and Durability of Rice Husk Ash Concrete. Iranian (Iranica) Journal of Energy \& Environment, 12(3), 204-208.

Krishna, N. K., Sandeep, S., \& Mini, K. M. (2016). Study on concrete with partial replacement of cement by rice husk ash. IOP conference series: materials science and engineering, 149(1), 012109.

Krishna, R., Chaudhary, M., \& Sen, A. (2015). Effect of partial replacement of cement by rice husk ash in concrete. International Journal of Science and Research, 4(5), 1572-1574.

Kundu, S., Aggarwal, A., Mazumdar, S., \& Dutt, K. B. (2016). Stabilization characteristics of copper mine tailings through its utilization as a partial substitute for cement in concrete: preliminary investigations. Environmental Earth Sciences, 75(3), 227.

Le, H. T., \& Ludwig, H. M. (2016). Effect of rice husk ash and other mineral admixtures on properties of selfcompacting high-performance concrete. Materials \& Design, 89, 156-166.

Map of Zambia showing rice growing area and provinces as discussed under the background. Retrieved from https://www.pinterest.com/pin/770467448725782191

Mo, K. H., Alengaram, U. J., \& Jumaat, M. Z. (2015). Utilization of ground granulated blast furnace slag as partial cement replacement in lightweight oil palm shell concrete. Materials and Structures, 48(8), 2545-2556.

Muhit, I. B., Ahmed, S. S., Amin, M. M., \& Raihan, M. T. (2013). Effects of silica fume and fly ash as partial replacement of cement on water permeability and strength of high-performance concrete. In 4th International Conference on Advances in Civil Engineering, AETACE, Association of Civil and Environmental Engineers.

Muleya, F. (2000). Quality management in Construction. Thesis. Zambia: Copperbelt University.

Muleya, F., \& Nwaubani, S. (2018). Sustainable Partial Cement and Water Replacement in Concrete Using PFA and Super Plasticiser. Case Studies Journal, 5(5), 3440.

Muleya, F., Mulenga, B., Zulu, S. L., Nwaubani, S., Tembo, C. K., \& Mushota, H. (2021). Investigating the suitability and cost-benefit of copper tailings as partial replacement of sand in concrete in Zambia: an exploratory study. Journal of Engineering, Design and Technology, 19(4), 828-849. doi: 10.1108/JEDT05-2020-0186

Muthadhi, A. A., \& Kothandaraman, R. (2007). Rice husk ash - Properties and its uses: a review. Journal of The Institution of Engineers (India), 88, 50-56.

Muthandhi, A., \& Kothandaraman, S. (2010). Optimum production conditions for reactive rice husk ash. $\mathrm{Ma}$ terials and Structures, 43(9), 1303-1315.

Naik, T. R. (2008). Sustainability of concrete construction. Practice Periodical on Structural Design and Construction, 13(2), 98-103.

Novikov, A. M., \& Novikov, D. A. (2019). Research methodology: From philosophy of science to research design. CRC Press.

Obilade, I. O. (2014). Use of rice husk ash as partial replacement for cement in concrete. International Journal of Engineering, 5(04), 8269.

Olafusi, O. S., \& Olutoge, F. A. (2012). Strength properties of corn cob ash concrete. Journal of Emerging Trends in Engineering and Applied Sciences, 3(2), 297-301.

Oyekan, G. L., \& Kamiyo, O. M. (2011). A study on the engineering properties of sandcrete blocks produced with rice husk ash blended cement. Journal of Engineering and Technology Research, 3(3), 88-98.

Özbay, E., Erdemir, M., \& Durmuş, H. İ. (2016). Utilization and efficiency of ground granulated blast furnace slag on concrete properties-A review. Construction and Building Materials, 105, 423-434.

Pal, S. C., Mukherjee, A., \& Pathak, S. R. (2003). Investigation of hydraulic activity of ground granulated blast furnace slag in concrete. Cement and Concrete Research, 33(9), 1481-1486.

Pode, R. (2016). Potential applications of rice husk ash waste from rice husk biomass power plant. Renewable and Sustainable Energy Reviews, 53, 1468-1485.

Podolyakina, N. (2016). Product reliability and warranty period as a cost-forming factors. Business: Theory and Practice, 17(4), 361-369. doi: 10.3846/btp.17.11131

Rafieizonooz, M., Mirza, J., Salim, M. R., Hussin, M. W., \& Khankhaje, E. (2016). Investigation of coal bottom ash and fly ash in concrete as replacement for sand and cement. Construction and Building Materials, 116, 15-24.

Rajagopalan, G. (2019). Durability of alumina silicate concrete based on slag/fly ash blends against corrosion. Engineering, Construction and Architectural Management, 26(8), 1641-1651. doi: 10.1108/ ECAM-08-2018-0345

Rajamane, N. P., Peter, J. A., \& Ambily, P. S. (2007). Prediction of compressive strength of concrete with fly ash as sand replacement material. Cement and Concrete Composites, 29(3), 218-223.

Ramezanianpour, A. A., Mahdikhani, M., \& Ahmadibeni, G. H. (2009). The effect of rice husk ash on mechanical properties and durability of sustainable concretes. International Journal of Civil Engineering, 7(2), 83-91.

Reshma, T. V., Manjunatha, M., Sankalpasri, S., \& Tanu, H. M. (2021). Effect of waste foundry sand and fly ash on mechanical and fresh properties of concrete. Materials Today: Proceedings. doi: 10.1016/j. matpr.2020.12.821 
Salvador, R. P., Rambo, D. A., Bueno, R. M., Silva, K. T., \& de Figueiredo, A. D. (2019). On the use of blastfurnace slag in sprayed concrete applications. Construction and Building Materials, 218, 543-555.

Sharma, R. K. (2014). Effect of substitution of cement with rice husk ash on compressive strength of concrete using plastic fibres and super plasticizer. KSCE journal of civil engineering, 18(7), 2138-2142.

Shukla, A., Singh, C. K., \& Sharma, A. K. (2011). Study of the properties of concrete by partial replacement of ordinary Portland cement by rice husk ash. International Journal of Earth Sciences and Engineering, 4(6), 965-968.

Siddika, A., Al Mamun, M. A., Alyousef, R., \& Mohammadhosseini, H. (2020). State-of-the-art-review on rice husk ash: A supplementary cementitious material in concrete. Journal of King Saud UniversityEngineering Sciences, 33(5), 294-307. doi: 10.1016/j. jksues.2020.10.006

Singh, A. (2008). Cost benefit analysis of green buildings. New Delhi: Department of building Engineering \& Management.

Singh, B. (2018). Indian Institute of Technology Roorkee, Roorkee, India. Waste and Supplementary Cementitious Materials in Concrete: Characterisation, Properties and Applications, 417-460. doi: 10.1016/B978-008-102156-9.00013-4

SNRDS (2016). Second National Rice Development Strategy 2016-2020. Retrieved from https://www.riceforafrica.net/images/countries/NRDS_rev/NRDS2_ Zambia_en.pdf

Swetha, K., Bhavya, S., \& Anadinni, S. (2015). Characterization of materials by partially replacing cement by copper ore tailing and sand by iron ore tailing. International Journal of Research in Engineering and Technology, 4(7), 374-377.

Thiedeitz, M., Schmidt, W., Härder, M., \& Kränkel, T. (2020). Performance of rice husk ash as supplementary cementitious material after production in the field and in the lab. Materials, 13(19), 4319.

Van Lam, T., Bulgakov, B., Bazhenov, Y., Aleksandrova, O., \& Anh, P. N. (2018, June). Effect of rice husk ash on hydrotechnical concrete behavior. In IOP Conference Series: Materials Science and Engineering, 365(3), 032007.

Zambia's rice production from 1978 to 2019. Retrieved from https://knoema.com/atlas/Zambia/topics/Agriculture/Crops-Production-Quantity-tonnes/Ricepaddy-production

Zareei, S. A., Ameri, F., Dorostkar, F., \& Ahmadi, M. (2017). Rice husk ash as a partial replacement of cement in high strength concrete containing micro silica: Evaluating durability and mechanical properties. Case Studies in Construction Materials, 7, 73-81. 